Review article UDC [130.2:62]:316.423.6

doi: $10.21464 / \mathrm{sp} 31106$

Received January $27^{\text {th }}, 2015$

\author{
Kurtul Gülenç ${ }^{1}$, Mete Han Aritürk ${ }^{2}$ \\ ${ }^{1}$ Mimar Sinan Fine Arts University, Faculty of Science and Letters, Department of Philosophy, Bomonti Campus, \\ Silahsor Street 89, TR-34360 Sisli, Istanbul \\ ${ }^{2}$ Dokuz Eylül University, Faculty of Letters, Tinaztepe Campus, TR-35390 Buca/Izmir \\ ${ }^{1}$ kgkurtulg@gmail.com, ${ }^{2}$ metehanariturk@gmail.com
}

\title{
Is Human Emancipation through Technology Possible?
}

\section{Abstract}

In the paper "The 'Bubbling Up' of Subterranean Politics in Europe”, which was published in 2013 in the Journal of Civil Society, Mary Kaldor and Sabine Selchow attempted to reveal the specific qualities of the uprisings which emerged after the year 2010 in some European countries, such as Germany, Spain, Italy, England etc. According to the authors, the mode of organization which forms the main body of these emancipatory movements obtains its basic logic from the world of the Internet. The use of the Internet requires a re-evaluation of negative philosophical commentary regarding technology. In the context of the twentieth century philosophy, Martin Heidegger and Herbert Marcuse are the most influential philosophers who studied on the negative aspects of technology. Heidegger portrayed the destructive effects of scientific reasoning and technology on the Western culture through the criticism of the traditional Western metaphysics on a phenomenological-ontological level. Marcuse, belonging to the tradition of Western Marxism, formed his critique of technology in the context of the concept of instrumental rationality and the critique of advanced industrial society and capitalism. Although the starting points of their perspectives on technology and the underlying purposes of their critiques of technology were different, it may be asserted that both have a rather negative and almost entirely pessimistic disposition towards technology. Heidegger's and Marcuse's criticisms of technology will be discussed in this context and the differences and similarities between these criticisms will be shown. Finally, the paper will emphasise the question of the possibility of a positive role of technology. Technology can serve as an alternative to negative uses by shedding light on the relation between the current uprisings and the Internet.
\end{abstract}

\section{Keywords}

technology, rationality, freedom, enframing, criticism, revolt movements, Internet, politics

The world history has always been full of revolts, rebellions and revolutions. However, the widespread use of the internet in the last two decades, and especially the use of social media during the last decade, have had a significant impact on the pace and the way these movements are formed. It seems that it's not possible to deny the role of online networking in recent protests across the USA, Europe and the Middle East. While it is possible to argue that the internet had an impact on the social movements that took place in the early 2000 s, such as Colour Revolutions, it was especially the impact of the social media on such social movements that reached undeniable dimensions in the 2010s, as seen in the cases of Arab Spring and the Occupy movements that started in the USA and spread to Europe. Mary Kaldor's and Sabine Selchow's article 
entitled "The 'Bubbling Up' of Subterranean Politics in Europe", ${ }_{1}^{1}$ published in the Journal of Civil Society in April 2013, seems to support this evaluation which was based on a simple assessment. The article, based on a quite comprehensive empirical study, focused especially on revolt movements ${ }^{2}$ in various European countries - Germany, Spain, Hungary, Italy, England, etc. - after the year 2010 and it attempted to explore the characteristics peculiar to these movements. According to the authors, one of the prominent features of these revolt movements was their way of organising.

The style of organisation that composes the main body of these movements was identified as online activism. This way of organising is based on horizontal relations, unlimited variability and, finally, an absence of leadership. The logic of the Internet world gives this type of organisation its main character. Both instrumental and substantial features of the Internet, expanding with each passing day, were determinative in these movements. The instrumental feature of the Internet serves two purposes: to organise masses and to mobilise masses. ${ }^{3}$ The substantial feature of the Internet is associated with having the power of determining the ethos of collective production and reproduction. In other words, masses are striving to create a new culture of political organisation, both in real life and on the Internet. There is an attempt to institutionalize this new culture, which is critical of both the objectives of existing politics and the way of practicing politics. In this context, it renders the practices of representative democracy into a controversial position as well. Therefore, it is possible to claim that the indicators of underground politics are the collective projects of re-imagining democracy, its practices, and its relation with the daily life. ${ }^{4}$

This empirical assessment, formed on the platform of the Internet culture and its connection with the recent social movements, requires the re-evaluation of the negative interpretations of technology in philosophical discourse. Martin Heidegger and Herbert Marcuse are the most influential philosophers who worked on the negative aspects of technology in the twentieth century philosophy. Heidegger portrayed the destructive effects of scientific reason and technology on the Western culture through the criticism of traditional Western metaphysics on a phenomenological-ontological level. Marcuse, a member of Western Marxism, formed his critique of technology in the context of the concept of instrumental rationality and the critique of advanced industrial society and capitalism. Although the starting points of their perspectives on technology and the underlying purposes of their critiques of technology were different, it may be asserted that both have a rather negative and almost entirely pessimistic perspective of technology. In this context, Heidegger's and Marcuse's criticisms of technology will be discussed and the differences and similarities between these criticisms will be shown. Finally, the paper will emphasize the question of the possibility of a positive role for technology, which can serve as an alternative to the negative perspective by shedding light on the relation between the current uprisings and the Internet.

$$
* * *
$$

Heidegger developed his thoughts on technology within the discussion related to the concept of truth, which he thoughts out through the process of settlement with the Western tradition of metaphysics. Just as the understanding of traditional truth covers the primordial understanding of truth, the instrumental meaning of technology covers its essence as well. In modern times, a conception regarding technology as a human activity and an instrument has 
become widespread, and it turned into an opinion accepted by the majority. Technology is a means to an end. Its instrumental characteristic is related to the fact that it is a human activity. Determining purposes and inventing and using instruments to reach the determined purposes is specific to humans. The author states that such a conception is an instrumental and anthropological definition/determination of technology. ${ }^{5}$ Nobody can easily ignore the correctness of this definition in relation to contemporary technology. However, that which is correct is not yet true because the conception which considers technology as a means to an end does not involve thinking about the essence of technology. Thinking about the essence of technology is always delayed in the instrumental approach:

"... technology is not equivalent to the essence of technology."

Yet in the modern times the difference between technology and its essence has been lost. Just as the primordial understanding of truth, with translating the question of forgetting or aletheia (which emerges when Being is seen as beings or as a characteristic of beings) into Latin as veritas, is masked, the difference between technology and its essence becomes vague as technology itself is conceptualised with its instrumental/anthropological definition:

"That is why the instrumental conception of technology conditions every attempt to bring man into the right relation to technology. Everything depends on our manipulating technology in the proper manner as a means. We will, as we say, 'get' technology 'intelligently in hand.' We will master it. The will to mastery becomes all the more urgent the more technology threatens to slip from human control."7

According to Heidegger, the modern people's relationship with technology is only a relationship of domination. In compliance with his previous analysis, Heidegger stated that the instrumental definition of technology is more visible as the ancient roots of the term 'technology' are being forgotten. Therefore, the question that needs to be asked is this: In what way do we confront these issues when we do not consider technology as simply an instrument? What 'framework' do we see when we do not address the instrumental characteristic of technology as its essence? To answer these questions, Heidegger explored the origin of the concept of technology. Again, this quest led the thinker to the world of Ancient Greece, particularly to the concept of techne,

The article in question resembles a summary of an approximately 60-page long report published by Mary Kaldor, who at the time directed the Civil Society and Human Security Research Unit in the London School of Economics, and led three researches in June 2012.

2

It is necessary to emphasize that not all movements in these areas are libertarian. For instance, it would be possible to say that some revolts, such as the one in Hungary, had nationalist and xenophobic characteristics. Thus, it is stated in the study that such movements have both promising and dangerous aspects. However, the researchers explained that they focus on the movements in which libertarian tendency was dominant. See Mary Kaldor, Sabine Selchow, "The 'Bubbling Up' of Subterranean Politics in Europe”, Journal of Civil Society IX (1/2013), pp. 78-99, p. 79. doi: http://dx.doi.org/10.1080/17448689.201 3.784501

3

Ibid., p. 89

4

Ibid., p. 88

5

Martin Heidegger, "The Question Concerning Technology", in: Basic Writings from Being and Time (1927) to The Task of Thinking (1964), Harper Collins Publishers, New York 1993 , p. 312

6

Ibid., p. 311.

7

Ibid., p. 313. 
which is related to technology. According to Greeks, all the things confronted are 'present', but 'present' derives from 'not present', and thus 'present' is bringing-forth. Coming into presence from that which is not present is poiesis. ${ }^{8}$ Techne is also a form of bringing-forth. In techne, human beings contributes to the bringing-forth of something by the means of art and handicraft. In other words, human beings contribute to the elements which contribute to the bringing-forth of something. In this respect, for Greeks, theoretical activities pertain to techne. Thinking means contribution to bringing-forth and accompanying it. "Thinking" helps the Being to reveal itself. Hence, according to Heidegger, the question concerning technology eventually arrives at revelation, aletheia. Technology is more than means to an end. Technology is a way of revealing. Instrumentalism, considered as the basic characteristic of technology, also pertains to the realm of revealing. When we pay attention to this, a new realm, regarding the essence of technology, appears before us. It is the realm of revealing, i.e. of truth.

"Techne is a mode of aletheuein. It reveals whatever does not bring itself forth and does not yet lie here before us, whatever can look and turn out now one way and now another."9

This revealing constitutes the primordial understanding of technology.

Techne means the craft-like knowledge of the revealed, the existing; it is a mode of bringing-forth towards presence, a mode of revealing. And philosophy, which questions the truth and is a way of thinking, desiring to reveal itself in its own realm of existence, is a techne in its own style. The metaphysical thinking in the Western tradition emerged from this philosophical perspective, which brings the expression of techne into the modern times. However, this expression was developed on the basis of the will to control everything and secure its being. In the modern times, science emerged as one of the most important means of this will. Thus, according to Heidegger, scientific reason of the West has protected the metaphysical belief that addressing the causal basis as a real basis in an absolute and unconditional way is significant. The essence of the Western tradition of metaphysics has continued to exist in the scientific reason. Furthermore, the new subject organised around this reason is not positioned within nature, but against it. In that case, the complicated system of the techniques referred to as 'modern technique' or 'modern technology' pertains to the natural scientific realm of the new era. However, this assessment does not mean that technology depends on the new era science or, in other words, that the new era of science totally prioritises technology. Heidegger is definitely against this classic approach. He underscores that the New Era physics depends on the technical device and the advancement in the construction of the technical device. To Heidegger, the complicated system of techniques referred to as 'modern technique' or 'technology' belongs to the natural scientific realm of the new era. To put this claim into words means to suggest that the urge of the modern man to dominate everything in this realm is also seen in the field of technology. Technology addresses everything objectively, just as science does. The modern technician is expected to impose an order on data. As a matter of fact, he expects it as well. Therefore, he is the one who always keeps things under control. ${ }^{10}$ The difference between modern technique and the technique in the ancient period emerges within this framework. Both modern technology and the technique in the ancient period are a kind of revealing. However, it is the challenging which distinguishes the revealing of modern technology (for example, the machine-powered technology) from the revealing of a handicraftsman. The revealing involved in modern technology is a challenge. In this revealing, the truth, in the sense of aletheia, happens. ${ }^{11}$ Within this framework, Heidegger claims that 
“... the revealing that holds sway throughout modern technology does not unfold into a bringing-forth in the sense of poiesis. The revealing that rules in modern technology is a challenging [Herausfordern], which puts to nature the unreasonable demand that it supply energy which can be extracted and stored as such."12

In terms of its essence, modern technique is a revealing of challenging. It necessitates the struggle with everything existing. Necessity to struggle turns into an attack. Technology attacks everything and imposes on everything a demand to be seized for use..$^{13}$

The human being positions himself as the ruler of nature in the challenging revealing of technology. In this account, nature is regarded as nothing but a source which can be utilised by human beings. The human being is located in the centre of what is happening. Heidegger refers to this gathering of human beings within the order as enframing. ${ }^{14}$ Enframing is an epoch, one of the conditions for the possibility of experience. Human beings, in the epoch of enframing, claim to be the masters of Earth. ${ }^{15}$ In this epoch, technology is positioned as a tool for the purpose. In such a perspective, the essence of technology faces the risk of being forgotten.

The challenge of enframing which lies in the essence of modern technology brings with itself the danger of preventing the revealing of truth. The danger lies in the essence of technology as a destining of revealing. This complex situation can be understood only through emphasizing that technology threatens to get rid of human control to the extent that the will to dominate technology is essential, as Heidegger stated. ${ }^{16}$ Yet somehow a 'saving power' is said to appear out of this nightmare. However, this destining is not a danger in itself for humans. The danger lies in the essence of technology as a destining of revealing. In technological production, Earth is covered up. Human beings are promoted to the level of the lord of things, that is, from the state of being a medium to the state of revealing of earth. Human beings become the orderers and Earth becomes the reserve which is always ready at hand. ${ }^{17}$

Is it possible to get out of this nightmare? Somehow, a 'saving power' is said to appear out of this nightmare, claims Heidegger. What is this saving power

Ibid., pp. 317-318. It is necessary to state that poiesis does not only mean manufacture based on handcraft or artistic bringing into appearance. For Heidegger, it also means physis. In other words, the arising of something from out of itself is also bringing-forth - poiesis. The thinker exemplifies it as the bursting of blossom into bloom, from itself into itself.

Ibid., p. 319.

10

According to Heidegger, this control system reaches its extreme point with cybernetics and futurology.

11

Heidegger says that "technology comes to presence in the realm where revealing and unconcealment take place, where aletheia, truth happens". See M. Heidegger, "The Question Concerning Technology”, p. 319.

12

Ibid., p. 320.
13

"This setting-upon that challenges the energies of nature is an expediting, and in two ways. It expedites in that it unlocks and exposes." Ibid., p. 321

14

Ibid., pp. 325-326.

15

Dilek Arlı Cil, "The Relation between Technology and Truth in Heidegger's The Question Concerning Technology", Synthesis Philosophica 53 (1/2012), pp. 81-89, p. 87.

16

M. Heidegger, "The Question Concerning Technology", p. 313, 341 .

17

D. A. Çil, "The Relation between Technology and Truth in Heidegger's The Question Concerning Technology", p. 87. 
and what does it promise? Heidegger began his answer with a quotation from Hölderlin, authorizing his initial leap from the idea that the technological enframing is 'the danger' to the obscurely connected idea that with the danger a 'saving power' grows. ${ }^{18}$ Following this quotation, Heidegger said:

"If the essence of technology, enframing, is the extreme danger, if there is truth in Hölderlin's words, then the rule of enframing cannot exhaust itself solely in blocking all lighting-up of every revealing, all appearing of truth. Rather, precisely the essence of technology must harbor in itself the growth of the saving power." 19

That is to say, a saving power lies in enframing. Since this power is related to the arrival to the presence of truth, it is an indicator that human beings can be the guards of an opportunity. Within the context of the question concerning technology, there is a possibility of the happening of truth in technology by means of saving power as Being, and human beings come face to face in enframing. However, this encounter occurs in estrangement. In enframing, there is a path of danger and there is a path of brightly shining saving power. This shine moves humans and Being toward each other inside a darkness which is yet to be enlightened. It is related to freedom. According to Heidegger, freedom is not a matter of whether or not a human desires to determine particular things. Freedom cannot be addressed within the context of the causality paradigm. On the contrary, freedom means that a human being is drawn towards liberation by giving himself to the calls which direct him to it because specifically human beings and Being itself see the light of revealing. This light leads up to another opportunity for technology. This means talking about the possibility of overcoming technology. However, this discourse does not imply entirely giving up on technology. Technology will be overcome through itself in a way by which it can be re-established within its own essence.

\section{$* * *$}

Next to Heidegger, Herbert Marcuse is one of the main philosophers who problematized technology. In his work One-Dimensional Man, published in 1964, Marcuse analysed advanced industrial society and, according to him, the characteristic that distinguishes this society from the other types of societies is the level of technological rationality reaching into all fields of social life organised in the form of relations of capitalist production. As a result of this claim, it would not be a fault to say that, according to Marcuse, technology has risen to a massive power status that radically determines the lives and mentalities of individuals living in a modern society.

Every aspect of daily life is invested with the rational principle of the technologizing process in developed capitalist societies. To an extent, this means that human life becomes similar to it. The spreading of technology to every aspect of human life has created a system that eliminates differences. ${ }^{20}$ Marcuse, therefore, argues that a human being living in this system is a one-dimensional human being. To Marcuse, human existence seems to be reduced to one dimension in advanced industrial societies. The assessment underlying this thought is the idea that technology has replaced ontology in the modern times. $^{21}$ What is meant with this claim is that the natural world has turned into a technical world as a result of the technological advances arising with the progress of modern science. This one-dimensional reality lies behind the nihilistic appearance of the modern society. The autonomy of reason in the one-dimensional reality had already lost its significance when technology sur- 
rounded daily life. The modern subject, from which the power of criticism has been taken away with the blindly advancing technology, has been erased.

In One-Dimensional Man, in which the advanced status of industrial society in terms of technological rationalism is emphasised, Marcuse presented the analysis of the ethical-political and ontological aspects of this break. He believes that the rationality of industrial societies is directly linked to technology and thus it is possible for the current system to manipulate the desires and needs of individuals by using technology at will. ${ }^{22} \mathrm{~A}$ false system emerged from within such a structure, and this false system created false needs, and thus it was possible for this structure to reproduce itself through different organisations.

\section{According to Marcuse,}

“... loss of conscience due to the satisfactory liberties granted by an unfree society makes for a happy consciousness which facilitates acceptance of the misdeeds of this society. It is the token of declining autonomy and comprehension." 23

In this context, it would not be wrong to say that the modern individual unconsciously becomes a part of the power of the established socio-economic system to the extent that he is happy. As a result of the structure of "happy consciousness", individuals, and even society as a whole, have to believe that the modern society produces goods. The fact that individuals in the society believe that the system produces goods is directly related to the influence of technology. This influence of technology on human minds almost prevents individuals from establishing an idea of positive utopia in their minds.

Claus Offe claims that it is possible to group Marcuse's opinions on this issue in three theses. According to the first of these theses, scientific rationality has become the organisational principle of domination. Marcuse argued that the structure he called operationalism ${ }^{24}$ became the backbone of science and technology turned into a way of social control and dominance. In other words, technology functions as the founder of the rational ground for ruler's use of power, and it ensures its continuity. Inhumane management and manipulative intentions affect technology not only in regard to what technology is required to provide service for, but also concerning the basis of production of technology and even basic scientific research. ${ }^{25}$

18

"But where danger is, grows the saving power also." See M. Heidegger, "The Question Concerning Technology", p. 333.

19

Ibid., pp. 333-334.

20

Herbert Marcuse, "Some Social Implications of Modern Technology", in: Andrew Arato, Eike Gebhardt (eds.), Essential Frankfurt School Reader, The Continuum Publishing, New York 1998, p. 160.

21

Herbert Marcuse, "From Ontology to Technology: Fundamental Tendencies of Industrial Society", in: Stephen E. Bronner, Douglas M. Kellner (eds.), Critical Theory and Society: A Reader, Routledge, New York - London 1989, p. 121.
22

Claus Offe, "Technology and One-Dimensionality: A Version of the Technocracy Thesis?", in: Robert Pippin, Andrew Feenberg, Charles Webel (eds.), Marcuse: Critical Theory and The Promise of Utopia, Bergin \& Garvey Publishers, South Hadley (MA) 1987, p. 215.

23

Herbert Marcuse, One-Dimensional Man, Routledge, New York 2007, p. 79

24

It is an approach which suggests that all scientific terms and concepts need to be determined by empirical and applicable sciences.

25

C. Offe, "Technology and One-Dimensionality: A Version of the Technocracy Thesis?", p. 216. 
In this respect science became technological, and it has a structure with continuous direct applications providing practical benefits and opens itself for use (consumption). In this regard, the United States university system might be given as an example: in this system, universities conduct joint studies directly with private companies or government institutions such as the army, and they continuously carry out studies to develop technology. In such a structure, almost all research is financed by the international companies and the army, and thus science and technology start to serve the interests of these groups. The fact that the Internet, which is the most widely used technology in the world, was developed with the support of the US Department of Defence seems to prove it. ${ }^{26}$

According to Offe, in his second thesis Marcuse mentions the emergence of technology sui generis, i.e. as a distinctive autonomous technological rationality:

"Rational control over nature and bureaucratic control over the work process, either through integration or through effective repression of deviance, form the basis of the "happy consciousness' of a society that is practically unopposed." 27

Marcuse argued that liberal-capitalist democracies are a political system which enslaves its own society, dehumanises it, and creates fake needs required to be met by people. As we might deduce from Marcuse's approach, happiness in a class society, or, in a broad sense, techno-capitalist society, became parallel with the idea of consumption for almost all people. In this way, the individual seeking pleasure in consumption perpetually reproduces this system and isolates himself by intentionally or unintentionally fulfilling the duty given to him in the process of sustaining this system and serves the process of "reification" of social relations as a means to an end. That such a vicious circle is possible owes to the meta-cultural structure titled 'happy consciousness' by Marcuse, and results from the individuals' belief that the real is rational and that the system delivers goods. ${ }^{28}$ In the industrial society, as a result of the rationality determined by technology, the individual believes that he is happy when certain needs, marked as false needs by Marcuse, are satisfied. According to Marcuse, systematizing the needs of societies and individuals in this context and the elimination of progressive thought are realised at three stages, namely the economic, political, and cultural. The first stage is economic. Marcuse considered the working class' failure to realise their true needs at the economic level. At the political stage, the system is made unable to meet the true needs through a conscious industrial orientation and social manipulation techniques. At this stage there is an attempt to satisfy the false needs of the society itself. People do not pursue their true needs in terms of politics and thus individuals cannot participate in the struggle for their rights (or do not want to do so and prefer to remain silent in each situation) as they cannot make a distinction between the true and false needs. Finally, Marcuse addressed the cultural stage. In this stage, industrialised cultural and aesthetical expressions no longer have a value. Therefore, in losing their critical aspects, cultural-aesthetical elements become mere objects of consumption.

When One-Dimensional Man was written, "both Marxism and liberalism were unanimous in their praise for the new technological society coming into being". ${ }^{29}$ Hence, according to Offe, it might be possible to argue that the claims suggested in One-Dimensional Man by Marcuse are valid for socialist societies as well. The argument, referred to as Marcuse's third thesis by Offe, appears exactly at this stage. Thus it is not surprising that the third thesis proceeds with the argument that socialist societies, just as capitalist societies, are 
under the influence of technological rationality. Marcuse said that it is wrong to consider socialist societies as the models of freedom, because the industrialisation process in the Soviet Union, which is the homeland of socialism, prevented the emergence of new forms of freedom by imitating the forms of rationality in production and management processes in fact present in the capitalist societies. ${ }^{30}$ The industrial systems of the West and the Soviet Union are related in terms of their technological essences and competition. Thus, they follow the same path not only in terms of the satisfaction of human needs, but also in making human existence passive. This is because the close trade relations of the Soviet industrialism and the capitalist industrial structures pushed the Soviet society away from the opportunity to reach a structure enabling the realisation of freedom. According to Marcuse, the implementation of Western industrialism and its principles in the socialist industrial societies without any changes to the core idea led to the reproduction of the structures restricting human liberalisation and thus such industrialisation is intrinsically linked to the capitalist ideology. ${ }^{31}$ As a result, technology, whether the name of the system is real socialism or capitalism, became an indispensable element of all advanced industrial societies.

For both Heidegger and Marcuse, it is obvious that technology has an inevitable role in any kind of philosophical and scientific analysis regarding this world and the modern human-made world. In fact, according to both thinkers, it does not seem theoretically or practically possible to create new opportunities related to the human-made world without solving the problem of technology. In this framework, Heidegger and Marcuse opted to take a critical stand in their philosophical investigations regarding technology. Heidegger focused on the essence of technology within the concept of enframing by applying his radical critique of the history of metaphysics to the field of science and technology. On the other hand, Marcuse criticised calculative reason and the dominating system established and maintained by associating technology with rationality through the analysis of industrial society. In the criticism of technology by Heidegger and Marcuse, the commonplace that comes to the forefront is this: in the modern world, technology has a dominating character. This character reveals itself in the ontological critique of enframing in Heidegger, and this critique means that everything is intrinsically perceived as a kind of resource. In Marcuse, in the context of his theory of technocracy,

26

Mark Ward, "Celebrating 40 Years of the Net", BBC News 2009, available at http:// news.bbc.co.uk/2/hi/technology/833 1253 . stm (accessed on May 27, 2016).

27

C. Offe, "Technology and One-Dimensionality: A Version of the Technocracy Thesis?", p. 217 .

28

H. Marcuse, One-Dimensional Man, p. 87.

29

Andrew Feenberg, "The Bias of Technology", in: Robert Pippin, Andrew Feenberg, Charles
Webel (eds.), Marcuse: Critical Theory and The Promise of Utopia, Bergin \& Garvey Publishers, South Hadley (MA) 1987, p. 225.

30

Claus Offe, "Technology and One-Dimensionality: A Version of the Technocracy Thesis?", pp. 218-219.

31

Ibid. pp. 218-219. 
a critique is present that signifies the relationship between the sustainability of one-dimensional society and the production achieved through technology. ${ }^{32}$ The dominating characteristic of technology means that it functions as an element of oppression at both the social and natural level. There is an important assumption which makes such a claim possible and complete. It is the idea that science and technology cannot be regarded as a simple instrument separated from value, just as it is in the liberal perspective. Liberal instrumentalism sees technology mainly as a product of an objective effort and this effort naturally represents an attempt of freeing from any kind of value. Therefore, in such a perspective technology is very roughly described as an important instrument of humanity's progress or a cluster of instruments that can be used to attain goals chosen independently. ${ }^{33}$ Undoubtedly, Heidegger and Marcuse agreed that technology is considered as an instrument. However, such instrumentalization does not mean the conceptualisation of technology as a neutral realm. On the contrary, Heidegger showed that technology is not merely the servant of some predefined social purpose; it is an environment within which a way of life is elaborated. In that case, according to Heidegger, technology has a significant ontological influence and it is far from being neutral. This influence becomes clear in the relation between technology and the lifeworld. As technology colonises the lifeworld, everything "sucked up" into its purview, including the modern subject, is reduced to the ontological status of a resource to be optimised. ${ }^{34}$ Within our current technological "constellation" of intelligibility, "only what is calculable in advance counts as being". ${ }^{35}$ This technological understanding of being produces a "calculative thinking" which quantifies all qualitative relations, reducing all entities to bivalent, programmable "information", a digitised data that increasingly enters into what Baudrillard calls "a state of pure circulation". ${ }^{36}$

For Marcuse, the most crucial result of the spread of technological rationality into every field of social life is the loss of alternative perspective. In fact, this problem is essentially related to the fact that the bourgeois individual has lost critical perspective. The main reason for this is that technological rationality has completely eliminated autonomy and freedom, and replaced them with the principle of productivity and standardisation. Technological rationality created the network of unfreedom, spreading into every corner of daily life. The network of unfreedom means heteronomy. The autonomy of the reason had already lost its significance when technology surrounded daily life. The modern subject, from whom the power of criticism has been taken away with the blindly advancing technology, has been erased. All the wishes, desires, and decision-making mechanisms of people are shaped by the principles of the technical reason. The individual is only an instrument in the one dimensional society. He is the instrument of technology. He is entrusted with the implementation of the principles of technology and the reproduction of technological rationality. Technology and its rationality have become a part of an individual's nature, and this individual has lost the unique realm of experience in the capitalist life. For Marcuse, the correspondence of this situation in the existential realm is the idea that technology has replaced ontology.

The idea that technology has a character which completely dominates gives prominence to the problem of autonomy and, correspondingly, to the problem of human agency. Therefore, the question is what kind of answers Heidegger and Marcuse can give to the following issues:

"Can the historical impact of technology be humanly controlled, or does it operate according to its own autonomous logic? Is humanity capable of guiding the historical direction in which technology is taking us?"37 
To these questions Heidegger answered "no" because that which is the most essential about technology - namely the way in which it alters how reality appears for us - cannot be controlled. Heidegger wrote:

"No single man, no group of men, no commission of prominent statesmen, scientists, and technicians, no conference of leaders of commerce and industry, can break or direct the progress of history in the atomic age." 38

Although Heidegger stated that "technology will be overcome within itself in a way that it can be established in its own essence", he clearly gave an autonomous character to technology. Andrew Feenberg viewed this approach as a fatalistic substantivism and indicated that with such an attitude there would never be a place for a reformist understanding. ${ }^{39}$ In other words, Heidegger argued for a full emancipation from technological institutionalisation or from technological order. Marcuse's stand here may not be considered very different from Heidegger's. Marcuse also constructed the idea of autonomy peculiar to technology. Even though he did not put it as explicitly as Heidegger did, the philosopher's analysis regarding the advanced industrial society directed the reader to the thesis about technological determinism. As a matter of fact, referring autonomy to technology means the attribution of a kind of causality. Undoubtedly, the degree of causality in Marcuse's thesis creates a sort of hard technological determinism.

Marcuse's idea that the potentials of the empirical analytical sciences are consumed in the one-dimensionality of classifying sciences, that the manipulation of needs makes all social stratums and classes a part of the political and economic status quo, that the prevalence of technological structures and networks silences political resistance and improvements, and that technological rationality prevents the potentials of human liberation, are consistent in their own system, claims Offe. ${ }^{40}$ However, as it is well known, Critical theory elaborated the current social system through a transformation of the possibilities that might change it. Hence, it is expected from a philosopher who accepted the methodology of Critical theory not only to put forth the causes and consequences of the current situation, but also to reveal how it can change and

32

Iain Thomson, "From the Question Concerning Technology to the Quest for a Democratic Technology: Heidegger, Marcuse, Feenberg", Inquiry 43, pp. 203-216, p. 205, available at: http://www.unm.edu/ ithomson/QuestTech pdf (accessed on January 27, 2015).

33

Ibid. p. 206.

34

Ibid. p. 206.

35

M. Heidegger, "The Question Concerning Technology", p. 326.

36

I. Thomson, "From the Question Concerning Technology to the Quest for a Democratic Technology: Heidegger, Marcuse, Feenberg", pp. 206-207; Martin Heidegger, Discourse on Thinking, Harper \& Row Publishers, New York 1966, p. 46; Martin Heidegger, "Traditional Language and Technological Lan- guage", Journal of Philosophical Research XXIII (1998), pp. 129-145, pp. 136. doi: http://dx.doi.org/10.5840/jpr_1998_16. Jean Baudrillard, The Transparency of Evil, Verso, London 1993, pp. 4.

37

I. Thomson, "From the Question Concerning Technology to the Quest for a Democratic Technology: Heidegger, Marcuse, Feenberg", p. 207.

38

Martin Heidegger, Discourse on Thinking, p. 52.

39

Andrew Feenberg, Questioning Technology, Routledge, New York - London 1999, pp. 1-9.

40

C. Offe, "Technology and One-Dimensionality: A Version of the Technocracy Thesis?", p. 221 . 
what the possibilities are for the transformation that can eliminate previously analysed problems. In other words, Critical theory needed to present its possibility within the issue it addresses, i.e. the possibility of changing through critique. According to Offe, Marcuse abandoned the historical orientation of Critical theory with its "one-dimensionality" approach. He accepted that the delay of this change resulted from a structure, not temporary, but produced and reproduced by the technological universe. According to Claus Offe, Marcuse's strict technological determinism, which opposed Critical theory, made the task of change and transformation near impossible to fulfil.

As can be seen, there are many similarities between Heidegger and Marcuse. Both state that technology by its nature dominates human beings and society through establishing a relationship between technology and ontology, and within this framework the issue of human agency arises. ${ }^{41}$ To the reader it might be surprising that, at the beginning, the statements of the two philosophers about technology are so similar. However, this ideational closeness between the two is more understandable when we recall that Marcuse was in close contact with Heidegger in the 1920s. ${ }^{42}$ Despite this closeness, the disengagement process between the two in the beginning of 1930s led to a differentiation in their ideas. Although there are many similarities between Heidegger and Marcuse in the context of technology criticism, Marcuse criticised Heidegger on two points. According to Marcuse, Heidegger's thoughts represented an irrationalist ideology - Heidegger served national socialist ideology. ${ }^{43}$ Because National Socialism combined irrationalist ideology with a terrorist technocracy, Heidegger preferred to use science and technology towards the objectives set by the irrationalist approach. Although he criticised technology, his approach, which blessed irrationalism, served Hitler's Nazism. Marcuse's second criticism of Heidegger can in general be placed under the criticism of existentialism. There is no doubt that Jean-Paul Sartre, as well as Heidegger, got their share of this criticism. Marcuse, in his article written in the second half of the 1940s regarding Sartre's existentialism, criticised existentialist individualism and the existentialist ontology. According to Marcuse, existentialism is idealistic as a philosophical doctrine. Existentialism constructs abstract metaphysical and ontological characteristics by converting the concrete specific historical conditions of human existence. Thus existentialism becomes a part of the ideology which it attacks and for this very reason its radicalism is considered by Marcuse to be a pseudo-radicalism. ${ }^{44}$ In fact, Critical theory is not a philosophy that conceptualises the concrete historical conditions of human existence, it is a social theory.

Besides these criticisms, the most obvious difference manifests between the two philosophers in their views on science and technology. According to Heidegger, the complex system of techniques called 'modern technique' or 'modern technology' pertains to the natural scientific field of the new era. However, this remark does not mean that technology depends on the science of the new era. In other words, the science of the new era prioritizes technology as a whole. Heidegger is absolutely against this approach. While Heidegger emphasised that the Renaissance physics, with regard to the idea of experiment, depended on the technical device and on progress in the construction of devices, Marcuse argued that technology is a product of modern natural sciences, but this relationship evolved and turned into a process in which theory was subjected to practice. Technology, which arose as a result of the theory developed through natural sciences at the beginning, took control of the scientific approach and theory. Marcuse defined this as a sacrifice of theory for the sake of application. However, this is not a sacrifice that denies 
the existence of theory. In the new situation the effect and structure of theory is constrained by practice and the role of theory in scientific activity is undermined and considered as dependent on practice. All the limits and extent of the importance of theory are drawn and determined by practice. Science started to turn into a pragmatic device that aims only at obtaining "practical" results, while slowly abandoning theory. Practical objectives are what now organises scientific activity. The term 'practical' is used in a very narrow sense here, in the context of 'benefit'. In short, science was reduced to the logic of practice. As emphasised by Marcuse,

“... theoretical operationalism came to correspond to practical operationalism. The scientific method which led to the ever-more-effective domination of nature thus came to provide the pure concepts as well as the instrumentalities for the ever-more-effective domination of man by man through the domination of nature. Theoretical reason, remaining pure and neutral, entered into the service of practical reason." 45

This difference between the two thinkers is very important because Heidegger's point, namely that the Renaissance physics is dependent on technical devices and on the progress in the construction of those devices for the purpose of performing experiments, has led the philosopher to question the essence of technology. Taking this approach as a starting point, Feenberg put forth a philosophically stronger criticism in comparison to Marcuse's criticism of Heidegger. According to Feenberg, Heidegger has taken an essentialist position in his view regarding technology. Going even further, Feenberg stated that the fatalistic substantivism that emerged in Heidegger's criticism of technology emanates from his essentialist attitude. According to Feenberg, technological essentialism was actually shaped as a result of the technological determinism that emerged after the Second World War. It is believed that theories of technological determinism appeared after the war and that they are either criticised or praised because of the positive and negative effects on society. For this reason, determinism was transferred to essentialism with all effects intact. Heidegger, Ellul, ${ }^{46}$ and their followers ascribed negative essence

41

Maybe both Heidegger and Marcuse tended towards art because of this; they tried to find escape in the field of art.

42

It can be stated that the philosopher was Heidegger's student and that Marcuse attempted to combine Marxism and phenomenological existentialism at the beginning period of his theoretical activities.

43

Douglas Kellner, "Introduction", in: Herbert Marcuse, Technology, War and Fascism, Routledge, New York 2004, p. 6. doi: http:// dx.doi.org/10.4324/9780203208311.

44

Ibid., p. 34. Also see Herbert Marcuse, "Existentialism: Remarks on Jean-Paul Sartre's L'Etre et le néant", Philosophy and Phenomenological Research VIII (3/1948), pp. 309-336, p. 335.

45

H. Marcuse, One-Dimensional Man, p. 162.
46

Jacques Ellul also believed that technology has a specific structure. This structure explains its autonomous character. According to him: "Autonomous technology means that technology ultimately depends on itself, it maps its own route, it is a prime and not a secondary factor, it must be regarded as an 'organism' tending toward closure and selfdetermination: it is an end in itself. Autonomy is the very condition of technological development. This kind of autonomy corresponds precisely to what J. Baudrillard sees under the name of functionality when he says that 'functional qualifies not what is adapted to an end but rather what is adapted to an order or a system'." See Jacques Ellul, "The 'Autonomy' of the Technological Phenomenon", in: Robert C. Scharff, Val Dusek (eds.), Philosophy of Technology, The Technological Condition: An Anthology, Blackwell Publishing, Oxford 2003, pp. 386-397, p. 386. 
to technology because they believed that technology is a force of domination and totalitarianism. They also claimed that technology is used as a tool of exerting pressure on society or people. Since it is a demiurge of the modern world, it tends to shape the nature of human beings by different means of control. By this control, it constitutes the very structure of modern world and lived experience.

Iain Thomson rejected the essentialism accusation made by Feenberg against Heidegger. According to Thomson, Feenberg based his criticism on the concept of essence that was not accepted by Heidegger, but became traditional in the history of Western metaphysics.

"To understand the 'essence of technology', Heidegger says, we cannot think of 'essence' the way we have been doing since Plato (as what 'permanently endures'), for that makes it seem as if "by the (essence of) technology, we mean some mythological abstraction."

According to Thomson, we really need to think of 'essence' as a verb, as the way in which things 'essence' or 'remain in play'. Thus the essence of technology means the way in which intelligibility happens for us these days, that is, as "enframing". ${ }^{48}$ According to Thomson, when we follow this discourse we can reach the conclusion that Heidegger cannot be regarded as an essentialist in the field of technology, as was claimed by Feenberg. On the contrary, there is a parallelism between the historical understanding of essence defended by Feenberg and Heidegger's essence of technological perception.

Feenberg's further criticism of Heidegger is related to Marcuse's political criticism of the latter. Marcuse was defining Heidegger's idea as the ideology of irrationalism. Since the ideology of irrationalism denies reason, and therefore the free will of the subject, (its autonomy) in Marcuse's social theory, Heidegger's thought is positioned as a desperate heteronomy. Feenberg combines Marcuse's argument with Marx's concept of fetishism. Heidegger is a technological fetishist. In the Marxist vocabulary, fetishism occurs when a social relation between people assumes the fantastic form of a relation of things. For a Marxist, to fetishize something is to detach it from the human labour that produced it, yet to nevertheless continue to project human meanings onto it, mistaking these projections for an independent reality. The fetishist's anthropomorphic projection endows humanly created thing with the magical appearance of possessing a telos independent of human ends. In Feenberg's view, Heidegger's technological fetishism is visible in the fact that "technology rigidifies into destiny". 49 Thomson opposes Feenberg's interpretation, disagreeing with his attempt to combine Heidegger's concept of destiny with the concept of fetishism in Marxist literature in the context of the issue of technology. According to Thomson, Feenberg overlooked the fact that, for Heidegger, enframing is our destiny, but it is not necessarily our fate. Thomson refers to Dreyfus in order to deepen the subject. As Dreyfus put it,

“... although our understanding of things and ourselves as resources to be ordered, enhanced, and used efficiently has been building up since Plato and dominates our practices, we are not stuck with it. It is not the way things have to be, but nothing more or less than our current cultural clearing. In fact, the critical force of Heidegger's 'history of being' comes from his hope for a new historical beginning in which we would no longer treat everything as resources to be optimized." 50

According to Feenberg, it is obvious that Heidegger and Marcuse, in their arguments about technology, are essentially alluding to pacifism. Heidegger's approach calls for pacifism and echoes nostalgia. Here Feenberg agrees with his master Marcuse in the discussion on technology. However, it is not clear 
to us why he approves Marcuse's approach to technology while regarding Heidegger as a pacifist. While forming his own theory of technology, Feenberg stated that there is a need to combine the theories of democracy with critical social theory, therefore he referred to Marcuse. However, how Marcuse's analysis of technology will serve Feenberg's purpose is uncertain because, as seen beforehand, Marcuse, like Heidegger, also attributed a strong causality to technology and in the context of the theory of one-dimensional human being encountered problems of autonomy and human agency. One of the most concrete indicators of this problem is Marcuse's argument that the fact that an autonomous individual will turn into a nameless existent in a historical process is one of the results of ontology being replaced by technology.

Besides the fact that Marcuse's claim has a relative truth value, it can be said that the philosopher's approach to this subject is evoking excessive interpretations that drag us into a situation from which it is almost impossible to get out because the negative evaluations of technology have difficulty in explaining the source of the existence of the revolt movements or the grounds of radical critique organised over the Internet. Since the end of the 1990s, almost all anti-capitalist global resistance movements were organised through communication over the Internet. Likewise, the communication in the uprisings that emerged in the last decade was maintained through the Internet channels such as Twitter, Facebook, etc. Millions of people who have no concrete relationship with each other and who have never met faceto-face communicated and took action exclusively through the Internet. Beyond communication, the language and style used during the communication, especially by young people, played a major role in the popularisation of the opposition. In short, the Internet not only provided communication for the masses, but also contributed considerably to the creation of a new language and style of opposition. There is a basic problem to be solved: if we declare only the validity of the repressive, central and ideological functions of technological devices (we think that this is the common denominator for Marcuse and Heidegger regarding technology), we can easily claim that all these revolt movements were organised from a centre defined by imperialist powers or external powers. In other words, the arguments that intentionally or unintentionally completely negate technology (whether we call them essentialist or determinist) include a speculative interpretation of the emancipatory movements that people have organised by using technological devices. If liberty and technology are mutually exclusive and the people who live under the sovereignty of technological rationality have lost their autonomy, trapped in a mesh of false happiness and without the interest to demand any rights, then the emancipatory movements can only potentially emerge from something other than the will of the people. This conclusion, which does not sit well with Marcuse's overall political attitude, is, interestingly, a corollary of his conception of technological rationality.

47

I. Thomson, "From the Question Concerning Technology to the Quest for a Democratic Technology: Heidegger, Marcuse, Feenberg", p. 207.

48

Ibid., p. 208.
49

A. Feenberg, Questioning Technology, p. 14. 50

I. Thomson, "From the Question Concerning Technology to the Quest for a Democratic Technology: Heidegger, Marcuse, Feenberg", p. 209. 
At this stage, what kind of responses do we get if we repeat the question we posed at the beginning? Is human emancipation through technology possible? If we attempt to respond to this question with Heidegger's and Marcuse's analyses of technology, the response would not be positive. Although it is possible on paper to go beyond the existing situation by making a new and profound start for both of the philosophers, the conditions for the possibility of this beginning cannot be found in these philosophers' analyses of technology. Therefore, it can be claimed that not only Heidegger's technology analysis, but also Marcuse's conception of technological rationality and the one-dimensional theory of society which he developed on the axis of this perception, leads us to pacifism. The main reason for this is not the autonomy attributed to technology by the thinkers. Of course, it can be argued that technology has its own internal dynamics and that these internal dynamics trigger some kind of causality by creating specific characteristics. The important thing is the extent of technological determinism that is allowed by the authors. This must be analysed accurately and should not be taken as a social mechanism or a frame from which it is impossible to break free. Yet in both Heidegger and Marcuse, the dimension of the impact of the technological universe is reminiscent of a machine in which there is an absolute domination. In that case, in order to be able to attribute a positive function to technology, what needs to be done is either to entirely leave these approaches or reconstruct them. While shaping our arguments on technology, both of these options require a modification of the main principle on which the negative assessments are based. In this context, the first thing to be said about technology is that it does not have a character that dominates on the absolute and total level. Alongside accepting the presence of a unique and specific structure with the capacity for creating relative and objectionable hegemony, the said structure hosts a power that is historical, changeable, and can organise within a counter-hegemony. In other words, every program has its anti-program. This hypothesis enables us to revisit our arguments regarding technology.

Feenberg, who acts upon the following assumption, developed a new theory of technology: due to people's interests, the construction of technology is open to debate and exposed to change. Democratic and political change will not be complete and real without technical change because democratic political change also requires the radical change of technology and society, since they affect one another. Feenberg considered technology with its positive and negative sides and saw it as a contingent domain. According to him, we should pay more attention to its positive aspects and its ability to reconstruct, rather than to its negative aspects. Hence, questioning technology can weaken the solid nature of technology and it can make it more suitable for democratic discussion and reconstruction. In this context, Feenberg dealt with the idea of technocracy by integrating theoretical and cultural perspectives on technology. He provided an example of the democratic movement in 1968 in France in order to show how technology is shaped and opened to discussion by technocratic elites. This analysis involved the critique of technical control of the workplace, education, government, and culture by technocratic elites, and the critique of the programs for a more democratic participation and selfmanagement. ${ }^{51}$ Likewise, he argued that the most progressive elements in the ecology movement call for less-polluting, more sustainable technologies. However meaningful and valuable such an approach may be, it involves not only proposals such as less production, less population, or stylistic reformist 
practices, but also the revision and restructuring of environment technologies. ${ }^{52}$ In addition, Feenberg presented various examples to support his arguments. In Alternative Modernity, he claimed that people have a tendency to use technology for their interests rather than public's benefit. ${ }^{53} \mathrm{He}$ gave the example of the Minitel Videotex technology in France that allows people to get news, weather, and railway information suggested by the government. Later, the purpose of this technology was changed from getting news to interpersonal discussion. Feenberg kept on giving examples in this regard. He also provided studies of how women struggled for alternative childbirth technologies and practices, how AIDS patients militated for alternative medicine and healthcare, and how Japanese critiques of technology contained conceptions of alternative models of modernisation. ${ }^{54} \mathrm{He}$ really wanted to demolish the adverse effects of scientific determinism in line with Heidegger's and Marcuse's views on technology as a force dominating society and the individual. According to Feenberg, there is a close relationship between technology and democracy because both of them are contingent and affect each other. Kellner asserts that combining technology from philosophical standpoints and the usage of technology from political democratic viewpoints made Feenberg's thesis stronger and more successful. ${ }^{55}$ Feenberg talked about the notion of democratic rationalisation, which is summed up in his book Questioning Technology as follows:

“... new technology can also be used to undermine the existing social hierarchy or to force it to meet needs it has ignored." 56

This principle explains the technical initiatives that often accompany the structural reforms pursued by trade unions and social and environmental movements.

Briefly, using this principle, Feenberg argued that we need to recognise the possibility that technology could come to embody more democratic values. When we start from this claim, it can be argued that technology plays a significant role in terms of strengthening democratic values and in the process of emancipation. In this regard, it can be said that the Internet has a more specific function. As we stressed at the beginning of the study, the organisational style of the recently emerging revolt movements was described as online activism, and this style gets its basic logic from the Internet (most particularly Web 2.0) ${ }^{57}$ The two features in terms of instrument and essence pertaining

51

A. Feenberg, Questioning Technology, pp. $21 \mathrm{ff}$.

52

Ibid., pp. $67 \mathrm{ff}$.

53

See Andrew Feenberg, Alternative Modernity: The Technical Turn in Philosophy and Social Theory, University of California Press, Berkeley 1995.

54

Douglas Kellner, "Review-Article on Andrew Feenberg, Questioning Technology", UCLA $E D \& I S$, available at: http://pages.gseis.ucla. edu/faculty/kellner/essays/reviewandrewfeenberg.pdf, p. 4 (accessed on January 27, 2015).
55

Ibid.

56

A. Feenberg, Questioning Technology, p. 76.

57

The concept of Web 2.0 was put forth in 1999 by Tim O'Reilly and it led to the emergence of a new form of media with considerable power in the context of social media, mostly through the creation of a non-static version of World Wide Web open to change from users. Web 2.0 websites have user-generated content and it enables their users to interact and cooperate in a virtual community, unlike previous websites that were based on the passive visualisation of the content that was offered. 
to the Internet have been determining in the emergence of these movements. As a result of these properties, the Internet plays an important role in both strengthening democratic values and the emancipation of mankind by creating new values.

Many examples can be given to strengthen this observation. However, in order to understand the unique structure of the Internet, it will be useful to analyse television, which is one of the most important devices that also represented communication network before the Internet. The superiority of television, which became dominant the moment it appeared on the stage of history, is mainly related to the minimum-effort syndrome. ${ }^{58}$ Media studies indicate that only a small segment of people choose the program they will watch in advance, and in general people scan programs until they find the least boring or the most attractive one. ${ }^{59}$ In the light of this information, it would not be wrong to state that television is a unilateral communication tool that targets the least common denominator and attempts to homogenise its audience at least until the 1980s, when private channels first appeared. This structure of television turned it into a unilateral propaganda and entertainment box, and a tool used for uniformity in this framework. ${ }^{60}$ Since 1991 , when the first web site appeared, television has started to transfer its dominant role as a communication tool to the Internet. ${ }^{61}$ After that date the Internet was becoming more and more popular each day, and it created an alternative communication network in spite of the tendency of the television world to create uniformity. As of today, there are over 1 billion web sites on Internet and publications made on these sites that appeal to various opinions and different interests, and everyone can easily share their ideas. According to Castells

“... the price to pay for such diverse and widespread participation is to let spontaneous, informal communication flourish at the same time." 62

Communication that occurs on the Internet is in a spontaneous structure which displays great diversity in terms of its purpose and membership. ${ }^{63}$ As a result of this structure, according to Howard Rheingold, a new society model, in other words, virtual communities that gather people around common values and interests, has emerged. ${ }^{64}$ These virtual communities have proliferated and diversified in conjunction with the emergence of Web 2.0 and its product, social media, which can be defined as

“... the philosophy of mutually maximizing collective intelligence and added value for each participant by formalized and dynamic information sharing and creation." 65

With Web 2.0, the Internet was transformed from a structure where users were passive spectators into an active and constructive structure, undermining arguments that technology possesses a structure which establishes domination which transforms but is never transformed in any way. In other words, despite the interventions of the state and political structure, technology has an autonomous structure that operates itself. However, this structure is not a system which would not allow any changes, would be self-enclosed and would have an absolute integrity. As shown by Web 2.0 and the social media movement accompanied by it, no matter how hard governments and political powers try, they cannot easily control and completely censor the Internet, which is one of the greatest products of technology in our era. In addition to this, the Internet multiplies the existing life. In doing so, it both changes its user and its structure undergoes a transformation. However, it is not possible to make the same observations for television, which is another significant communication product of technology, because, according to Castells, there is a 
“... rise of ideological, militant journalism in all countries (actually a good business model in the U.S., e.g. Fox News or in Spain, e.g. El Mundo), as well as diminishing autonomy of journalists vis-à-vis their companies, and the intertwining between media corporations and governments. The practice of what Bennet (1990) has named 'indexing', in which journalists and editors limit the range of political viewpoints and issues that they report upon to those expressed within the mainstream political establishment, weighs heavily on the process of events-driven reporting. Yet the main issue is not the shaping of the minds by explicit messages in the media, but the absence of a given content in the media. What does not exist in the media does not exist in the public mind, even if it could have a fragmented presence in individual minds." ${ }^{\prime \prime} 6$

Despite this, manipulative and selective information transfer procedure in the context of the Internet is not as easy as it is in the context of television and newspaper because the masses consist of billions of users and countless virtual communities on the Internet consist of relatively aware members who carit be completely controlled with censorship or laws and who can reach news and information regardless of what the mainstream media presents. According to Castells, such an environment

“... offers an extraordinary medium for social movements and rebellious individuals to build their autonomy and confront the institutions of society in their own terms and around their own projects. Naturally, social movements are not originated by technology, they use technology. But technology is not simply a tool; it is a social construction, with its own implications." 67

Thereby, technology is not, as Heidegger and Marcuse claimed, a completely pacifying domination mechanism. Technology is a set of techniques which can be formed according to the way they are used and their purpose altogether. Besides being used as a one-sided propaganda tool, it can be used in a democratic and emancipatory way, as in the example of the Internet and social media. In addition, as seen in the example of the Internet, technology can give inspiration to the masses to the point of the emergence of new life styles. As a result of this, it would be reasonable to argue that human emancipation through technology is still possible.

58

Manuel Castells, The Rise of The Network Society, Wiley-Blackwell, Oxford 2010, p. 359. doi: http://dx.doi.org/10.1002/9781444 319514.

59

Ibid.

60 Ibid., pp. 360-361.

61

The first website (info.cern.ch) was launched on August 6, 1991 by British physicist Tim Berners-Lee at CERN in Switzerland.

62

M. Castells, The Rise of The Network Society, p. 383 .

63

Ibid.
64

Ibid., pp. 386.

65

Peter Knol, Marco Spruit, Wim Scheper, "The Emerging Value of Social Computing in Business Model Innovation", in: Patricia Ordóñez de Pablos et. al (eds.), Electronic Globalized Business and Sustainable Development Through IT Management: Strategies and Perspectives, IGI Global, Hershey (PA) 2011, pp. 112-134, p. 122. doi: http://dx.doi. org/10.4018/9781615206230.ch009.

66

Manuel Castells, "Communication, Power and Counter-power in the Network Society", International Journal of Communication, 1 (2007), p. 241.

67

Ibid., p. 249 


\title{
Kurtul Gülenç, Mete Han Aritürk
}

\section{Je li moguća ljudska emancipacija kroz tehniku?}

\begin{abstract}
Sažetak
U članku »The 'Bubbling Up' of Subterranean Politics in Europe«, objavljenom 2013. u časopisu Journal of Civil Society, Mary Kaldor i Sabine Selchow pokušale su otkriti specifične značajke pobuna koje su se javila nakon 2010. godine u europskim zemljama poput Njemačke, Španjolske, Italije, Engleske itd. Prema autoricama, način organiziranja koji čini glavno tijelo ovih emancipatornih pokreta preuzima svoju osnovnu logiku iz svijeta Interneta. Analogija s Internetom zahtijeva ponovnu evaluaciju negativnih komentara o tehnici iz filozofske perspektive. Martin Heidegger i Herbert Marcuse najutjecajniji su filozofi 20. stoljeća koji su se bavili negativnim aspektima tehnike. Heidegger je prikazao destruktivne učinke znanstvene racionalnosti i tehnike na zapadnu kulturu kroz kritiku tradicionalne zapadne metafizike na fenomenološko-ontološkoj razini, dok je Marcuse, kao predstavnik zapadnoga marksizma, oblikovao svoju kritiku tehnike u kontekstu pojma instrumentalne racionalnosti te kritike razvijenog industrijskog društva i kapitalizma. Iako su polazišne točke njihovih pogleda na tehniku, kao i osnovne svrhe kritike tehnike, različite, može se reći da obojica imaju poprilično negativno i gotovo u potpunosti pesimističko shvaćanje tehnologije. U tom će se kontekstu razmotriti Heideggerova i Marcuseova kritika tehnike kao i razlike i sličnosti između tih dvaju pristupa. Zaključno će rad naglasiti mogućnost pozitivne uloge tehnike, koja može služiti kao alternativa negativnoj perspektivi osvjetljavajući odnos između nedavnih pobuna i interneta.
\end{abstract}

\section{Ključne riječi}

tehnologija, racionalnost, sloboda, postav, kritika, pobunjenički pokreti, Internet, politika

\section{Kurtul Gülenç, Mete Han Arıtürk}

\section{Ist die Emanzipation des Menschen durch Technologie möglich?}

\section{Zusammenfassung}

In dem Artikel ,, The 'Bubbling Up' of Subterranean Politics in Europe”, veröffentlicht im Jahre $2013 \mathrm{im}$ Journal of Civil Society, versuchten Mary Kaldor und Sabine Selchow die spezifischen Qualitäten der Aufstände zum Ausdruck zu bringen, die nach 2010 in den europäischen Ländern ausbrachen - Deutschland, Spanien, Italien, England usw. Nach Ansicht der Autoren erhält der Modus der Organisation, der den Hauptkörper dieser emanzipatorischen Bewegungen bildet, seine grundlegende Logik aus der Welt des Internets. Die Analogie mit dem Internet erfordert eine Neubewertung der negativen Kommentare über die Technologie aus philosophischer Perspektive. Martin Heidegger und Herbert Marcuse sind die einflussreichsten Philosophen, die sich mit den negativen Aspekten der Technologie in der Philosophie des 20. Jahrhunderts befasst haben. Heidegger schilderte die zerstörerischen Auswirkungen der wissenschaftlichen Vernunft und Technologie auf die westliche Kultur durch die Kritik an der traditionellen abendländischen Metaphysik auf der phänomenologisch-ontologischen Ebene, während Marcuse, ein Mitglied des westlichen Marxismus, seine Kritik an der Technologie im Rahmen des Konzepts der instrumentellen Rationalität und der Kritik der fortgeschrittenen Industriegesellschaft und Kapitalismus geformt hat. Obgleich die Ansatzpunkte ihrer Perspektiven über die Technologie und die zugrunde liegenden Zwecke ihrer Kritik an der Technologie unterschiedlich waren, kann behauptet werden, dass beide eine eher negative und fast völlig pessimistische Einstellung zur Technologie hatten. In diesem Zusammenhang werden Heideggers und Marcuses Kritiken an der Technologie diskutiert sowie Unterschiede und Ähnlichkeiten zwischen den beiden Kritiken aufgezeigt. Abschließend unterstreicht das Paper die Frage nach der Möglichkeit einer positiven Rolle für die Technologie, die als Alternative zur negativen Perspektive dienen kann, indem sie Licht in das Verhältnis zwischen aktuellen Aufständen und Internet bringt.

\section{Schlüsselwörter}

Technologie, Rationalität, Freiheit, Gestell, Kritik, Revoltebewegungen, Internet, Politik 


\section{Kurtul Gülenç, Mete Han Arıtürk}

\section{L'émancipation humaine est-elle possible à travers la technologie ?}

\section{Résumé}

Dans l'article "The "Bubbling Up" of Suberranean Politics in Europe » publié en 2013 dans Journal of Civil Society, Mary Kaldor et Sabine Selchow tentent de mettre en lumière les caractéristiques spécifiques des révoltes qui ont fait jour après 2010 dans certains pays européens - Allemagne, Espagne, Italie, Angleterre, etc. Selon nos auteures, le mode d'organisation qui a formé le corps essentiel de ces mouvements émancipatoires tire sa logique de base du monde de l'internet. Cette analogie avec l'internet requiert une réévaluation, à partir d'un point de vue philosophique, des commentaires négatifs sur la technologie. Martin Heidegger et Herbert Marcuse sont les philosophes les plus influents ayant travaillé sur les aspects négatifs de la technologie au sein de la philosophie du XXe siècle. Heidegger a dépeint les effets destructeurs de la raison scientifique et de la technologie de notre culture occidentale à travers son criticisme de la métaphysique traditionnelle occidentale à un niveau phénoménologico-ontologique, tandis que Marcuse, membre du "communisme occidentale», a formé une critique de la technologie au sein du concept de rationalité instrumentale et une critique de la société industrielle avancée et du capitalisme. Bien que le point de départ de leur perspective sur la technologie et que le but sous-jacent de leur critique diffèrent, il est possible d'affirmer que leur point commun est d'avoir posé un regard négatif et presque entièrement pessimiste sur la technologie. À cet égard, le criticisme d'Heidegger et de Marcuse vont être abordés afin d'en soulever les différences et les similarités. Enfin, cet article mettra l'accent sur la possibilité d'un rôle positif de la technologie qui pourrait servir d'alternative aux perspectives négatives en faisant la lumière sur le lien entre les révoltes actuelles et l'internet.

\section{Mots-clés}

technologie, rationalité, liberté, mettre en forme, criticisme, mouvements de révolte, internet, politique 